Volume II - Article 2
Alcohol Ignition Interlocks: Magic Bullet or Poison Pill?
Gregory T. Neugebauer
Spring 2002

Copyright (C) 2002 University of Pittsburgh School of Law Journal of Technology Law and Policy

\title{
Introduction
}

The National Highway Traffic Safety Administration ("NHTSA") recently published some sobering statistics on drinking and driving. [1] A person dies on America's highways in an alcohol-related fatality every 33 minutes. A person is injured every 2 minutes. Approximately one third of all Americans will experience an alcoholrelated crash at least once in their lives. A staggering 1.4 million people "one for every 132 licensed drivers" were arrested for driving under the influence in 1998 alone. As if this human toll is not alarming enough, alcohol-related crashes cost Americans over $\$ 100$ billion annually.

In July of 1998, the federal government enacted yet another statute in a long line of laws aimed at encouraging states to stem the carnage occurring on our nation's highways. However, this statute, the Transportation Equity Act for the 21st Century ("TEA 21") Restoration Act, [2] has one dramatically new provision. Instead of relying exclusively on the traditional putative measures designed to curb impaired driving, e.g. incarceration, license suspension, vehicle seizure, it adopts a novel, technological approach. The Act calls for the installation of alcohol ignition interlocks in the vehicles of repeat offenders. [3]

An alcohol ignition interlock prevents a driver from operating a vehicle unless her breath sample has an alcohol level below a preset limit. [4] While such devices have been around since the 1960's, recent technical advances have made them easy to install, easy to operate, affordable, [5] accurate, ethanol specific, and "most importantly" difficult to circumvent. [6] Alcohol ignition interlocks have emerged as a powerful tool in keeping recidivist DUI [7] offenders from driving drunk.

Not surprisingly, the Congress, [8] government agencies, [9] advocacy groups, [10] and state courts [11] have welcomed these devices with barely a ripple of dissent. Today, over forty states, [12] including Pennsylvania, [13] can require drivers convicted of multiple DUI offenses to install an ignition interlock device as a condition for restoration of driving privileges. The strongest proponents of interlocks even advocate making it mandatory safety equipment, like seat belts and air bags. [14] Before the interlock bandwagon rolls too far, however, it may be prudent to consider some of the legal consequences of this new technology. 
While over forty states have adopted interlock measures, how firm is the constitutional footing of these statutes? Even if such laws are appropriate for repeat offenders, what about a universal, national interlock program? Could an interlock in every vehicle have unforeseen consequences? Interlocks might be an effective means to curb drunk driving, perhaps even the most effective, but are there any unforeseen liability and privacy issues to consider?

This comment examines some of the legal issues associated with alcohol ignition interlocks. It looks at interlocks from the perspective of both the DUI offender as well as the non-offender. Part I of this comment introduces interlock technology. Part II examines interlock statutes and how the courts have interpreted and applied them. Since interlock statutes are the progeny of state law, the focus is mainly on state courts. Part III evaluates possible constitutional challenges to interlock statutes. Part IV looks at the consequences of requiring this device in all vehicles, like airbags and seat belts. It also suggests legislative guidelines should Congress see fit to implement such a measure.

\section{Interlock Technology}

The typical unit of measurement of blood alcohol concentration ("BAC") used throughout the United States is percent (\%). [15] A BAC of 0.10\% represents 0.1 grams of ethanol per 100 milliliters of blood, [16] which equates to 0.1 grams per 210 liters of breath. [17] Indiana enacted the first BAC limit of 0.15\% in 1939. [18] Today, all states have BAC limits of either $0.10 \%$ or $0.08 \%$, with $0.08 \%$ being the most common. [19] Measurement of BAC via a deep lung, or "alveolar," air sample is the basic operating principle of most modern ignition interlocks. [20]

Ignition interlocks employ one of two basic types of sensors to measure the breath alcohol concentration "BrAC": a semiconductor sensor or an electrochemical sensor. [21] Each type of sensor has its relative advantages and disadvantages, although both types are commercially available.

The semiconductor sensor, also called a solid-state or Taguchi sensor, measures alcohol by detecting the change in electrical resistance of a circuit exposed to volatile hydrocarbons. [22] The major advantages of this sensor are its accuracy, low price, and its durability. [23] However, this sensor suffers from two significant drawbacks. First, the device requires frequent calibration. [24] Second, the device is not specific to alcohol. Many hydrocarbons including motor vehicle exhaust and even cigarette smoke affect the response. [25] Either of these drawbacks may produce an unacceptably high frequency of false positive readings, which greatly hinders the efficacy of the interlock program. False positive readings unjustly prevent the driver from operating the vehicle, and they prevent the program supervisor from determining whether the operator is attempting to drink and drive. The electrochemical or fuel cell sensor overcomes both these drawbacks.

An electrochemical sensor measures alcohol concentration by detecting the electrical current generated by the oxidation of alcohol. [26] This sensor has greater 
stability in calibration, which reduces maintenance requirements. [27] More importantly, the device is specific to ethyl alcohol, thereby greatly reducing false positives. [28] Its relative disadvantage is its higher cost. [29]

While both the semiconductor and fuel cell sensor technologies have clear relative advantages and disadvantages, either type of sensor can perform satisfactorily. [30] This is because an ignition interlock's usefulness does not depend on its ability to make precise distinctions in BAC levels. Its purpose is simply to determine whether a person's BAC is above or below a preset lockout limit. [31] As the fundamental purpose of the ignition interlock is to prevent an intoxicated person from operating a vehicle, the BAC cutoff is usually safely set to a small, non-zero value, typically 0.025\%. [32] This small level compensates for drift in the zero-point calibration value, thereby greatly reducing false positives, while, at the same time, minimizing the risk of an alcohol-impaired driver operating a vehicle. [33]

In addition to advances in alcohol sensor technology, there have been improve-ments in the prevention of interlock circumvention and tampering. Circumven-tion or tampering refers to any attempt to bypass the ignition interlock through mechanical or electrical means, or by providing a bogus air sample. [34] A key tool in hampering attempts to bypass the interlock is a data recorder. [35]

A data recorder documents all uses of the vehicle as well as all attempts to circumvent or tamper with the device. [36] Among the parameters recorded are: date and time of vehicle use, pass/fail records, BrAC levels, all attempts to disengage the device, and maintenance records. [37] A means for backing up the data is necessary in case of power interruption. [38] Along with the data recorder, another anticircumvention feature is the "rolling retest" requirement. This requires the driver to supply another breath sample between 5 and 30 minutes after starting the vehicle. [39] The rolling retest is the most effective means to thwart circumvention of the interlock by having a surrogate provide a breath sample at the curb. [40] Failure of the rolling retest does not risk catastrophe by disabling the vehicle. The data recorder merely logs the failure. [41] Additional appropriate action might include flashing the headlights, setting off an alarm, or locking out the driver unless she reports to a service center after a specified number of days. [42]

Today there are at least eight companies manufacturing alcohol ignition interlocks. [43] In response to the growing number of states requiring “certified” interlocks for DUI offenders, NHTSA, on April 7, 1992, issued a notice of certification standards and test procedures for these devices. [44]

\section{Interlock Statutes and the Courts}

This part examines several interlock statutes along with both federal and state court challenges to them. 


\section{A. Federal Law}

The federal government forcefully encouraged state acceptance of ignition interlocks when it enacted the TEA 21 Restoration Act on July 22, 1998. [45] Section 164 of the statue calls for the transfer of a portion of a state's 23 U.S.C. $\S 104$ federal highway construction funds to $\S 402$ highway safety programs unless the state enacts a federally approved repeat intoxicated driver law. [46] Section 164 sets forth the criteria that a state's repeat intoxicated offender statute must meet in order to preserve its full $\S$ 104 apportionment. [47]

An approved "repeat intoxicated driver law" is a state law that provides for the following minimum penalties for a driver convicted of two or more DUI offenses. The offender must receive a driver's license suspension for not less than one year. [48] Each of the driver's vehicles must be impounded, immobilized, or have an ignition interlock installed at the conclusion of the 1-year license suspension. [49] The state must assess the driver's level of alcohol abuse and treatment. [50] Finally, the state's repeat intoxicated driver law must mandate certain minimum levels of community service or periods of incarceration, depending on the number of previous convictions. [51] Determination of each state's compliance with these provisions rests with the Secretary of the Department of Transportation. [52]

Upon enactment of the federal rules for enforcing the TEA 21 Restoration Act on October 4, 2000, only 12 states required repeat DUI offenders to install an ignition interlock at the close of their license suspension. [53] Today, over forty states satisfy the $\S 164$ impoundment-immobilization-interlock provision through the interlock requirement. [54]

\section{B. Challenges to Interlock Programs in State Courts}

California became the first state to enact an ignition interlock statute in 1986. [55] Today, the California Vehicle Code mandates the installation of an interlock device for a subsequent DUI conviction, and it grants the courts discretion to order installation for a first offense. [56] A multiple offender must install an interlock in every vehicle that he owns or operates for a period not to exceed three years. [57] California's interlock statute provides for several "interest of justice” exceptions including one catch-all provision enabling the court to balance the hardship imposed on the offender with the likelihood that she will drink and drive again. [58] This allows, but does not require, each county to pay the interlock costs of the indigent. [59]

Since the adoption of its first interlock statute in 1986, a significant challenge to the California law has yet to reach its courts. Since 1985, only two published California opinions have so much as mentioned the statute. In People v. Gangemi, the Court of Appeal approvingly cited $\S 1203.1 \mathrm{~b}$ of the vehicle code, which requires the DUI offender to pay for her interlock, as an example of the legislature properly requiring a probationer to pay her probation expenses. [60] Similarly, in People v. Calvert, the same court noted 
the state's specifications for signs advertising the installation of ignition interlocks to show that automobile repair shops are a closely regulated business. [61] While California's interlock statute may not have yet faced a serious constitutional challenge, it has at least withstood the test of time.

New York's interlock statute has had a court history of interpretation very similar to California's, i.e. silence. However, its statute differs in one significant aspect in that requiring the DUI offender to install the device is totally discretionary with the court. [62] For this reason, New York does not comply with the TEA 21 Restoration Act's impoundment-immobilization-interlock provision via its interlock statute. [63] While no published New York opinion rules on a challenge to its interlock statute, one decision by the state's highest court devotes a few paragraphs of dicta to the subject in People v. Letterlough. [64]

In Letterlough, the court considered whether a trial court could require a six-time drunk driving offender to attach a fluorescent sign to his license plate reading "convicted dwi." [65] At issue in the case was whether the courts authority to require a defendant to "satisfy any other conditions reasonably related to his rehabilitation," comported with the state's penal law governing conditions of probation. [66] In rejecting a lower court's ruling that this "catch-all provision" permitted the court to fashion such a remedy, the Court of Appeals, favorably cited the state's interlock statute. [67]

The Letterlough court used the recent enactment of the state's interlock statute to show that the legislature was aware of the innovative tools available to combat recidivist drunk driving. [68] The court further noted that the legislature, by passing the interlock statute, clearly viewed that enabling legislation must authorize the court's authority to permit a case-by-case inquiry on whether to order installation of an interlock. [69] For this reason, the court rejected the notion that requiring a driver to attach a "convicted dwi" sign to his license plate is permitted in the absence of a positive grant of authority from the legislature. [70]

While the interlock statute was not at issue in Letterlough, it nevertheless strongly suggested that a majority of justices on New York's highest court are favorably inclined towards the interlock program. Certainly, had a majority on the court felt that the statute might be constitutionally unsound, they would not have used it as an example of an appropriate DUI sanction. At the very least, New York's and California's interlock statutes have met with passive acceptance by the courts. [71] In other states, the interlock challenge was more substantial.

In an Ohio case, a DUI defendant challenged a lower court's finding that the arresting police officer had probable cause to arrest him for DUI. [72] During a traffic stop of the defendant's vehicle, the officer noticed an ignition interlock device connected to an air compressor. [73] Suspecting that the driver had used the compressor to provide a bogus air sample, the officer asked him to start his vehicle by blowing into the device. [74] When the driver could not start his vehicle, the officer placed him under arrest for DUI. [75] In affirming the DUI conviction, the appellate court considered the 
defendant's inability to start his vehicle with the interlock one of the key elements in determining probable cause for arrest. [76]

In another Ohio case, City of Lakewood v. Hartman, the Supreme Court of Ohio squarely turned back a challenge to the state's interlock program. [77] In City of Lakewood, the sole issue before the court was whether the trial court abused its discretion in ordering the installation of an interlock when the defendant pled guilty to driving with a suspended license. [78] In this case, the appellant did not directly challenge Ohio's interlock statute, since her offense, driving with a suspended license, was not alcohol related. [79] Here, as in New York's Letterlough, [80] the appellant challenged the lower court's interlock order as being beyond the court's authority granted under Ohio's catchall probation provision. [81]

In affirming the order, the City of Lakewood court reasoned that installation of an interlock was an appropriate probation condition. [82] Although her conviction was not alcohol related, the court found a sufficient nexus between the court's order and the reason for her license suspension her four previous DUI convictions. [83] The City of Lakewood court viewed the interlock as a means to achieve two acceptable goals of probation conditions: protecting others from her irresponsibility, and deterring her from future criminal behavior. [84] The Ohio court also expressed its satisfaction with the rehabilitative value of the interlock program. It pointed out that the defendant faced a much harsher sentencing alternative: six months in jail and a \$1,000 fine. [85] The court opined that installing an interlock permitted the defendant, a single mother, to continue working and caring for her children, something the traditional sentencing scheme would not permit. [86]

In another important interlock case, the Supreme Court of Iowa upheld an equal protection challenge to its interlock statute in Iowa Department of Transportation v. Iowa District Court for Pottawattamie County (hereinafter "Pottawattamie County"). [87] In Pottawattamie County, the appellant argued that the trial court erred in ruling that he was ineligible to participate in the interlock program. [88] Central to his challenge was the lower court's interpretation of Iowa's interlock statute, § 321J.4, [89] in light of the motor vehicle habitual offender law, § 321.555. [90]

Iowa's motor vehicle law defines a "habitual offender" as anyone accumulating three or more DUI convictions within a six-year period, driving with a suspended license, or a half dozen other vehicle-related offenses. [91] The statute provides for the revocation of the offender's license for a period of two to six years, depending on the nature of the underlying offenses. [92] Passage of the state interlock statute created an exception to a portion of the habitual offender law. [93] The interlock statute provides that any person having three DUI convictions or three suspended license convictions may apply for a restricted license upon proof of installation of an ignition interlock. [94] The defendant in Pottawattamie County had one DUI conviction and two suspended license convictions; consequently, the department of transportation revoked his license under the habitual offender statute and ruled him ineligible for the interlock program. [95] 
The defendant challenged the interlock statute as irrational and as a violation of the equal protection clauses of the state and federal constitutions. He argued that the Iowa legislature had no rational basis for discriminating between a habitual offender with three convictions for DUI or suspended license and an offender, such as the defendant, with one DUI and two license suspensions. [96] In rejecting this challenge, the Supreme Court of Iowa applied traditional equal protection analysis using the rational basis test. [97]

Under the rational basis test, the challenged statutory classification is permissible if it rationally furthers a legitimate state interest. [98] The law is presumed constitutional and every lingering doubt is resolved in favor of the state. [99] The defendant "must negate every conceivable basis which may support the classification and the classification must be sustained unless it is patently arbitrary and bears no relationship to the legitimate governmental interest." [100] Applying this test, the Pottawattamie County court concluded that the legislature could rationally determine that a habitual offender with one DUI conviction and two suspended license convictions deserves different treatment than a defendant with three convictions for the same offense. [101] The Iowa court, therefore, affirmed the constitutionality of the interlock statute. [102]

More recently, in Meanor v. State, a convicted DUI driver called upon Maryland's highest court to determine whether Maryland's new interlock program [103] changed the advice that police must give a driver who refuses to take a blood alcohol test. [104] Maryland law requires that an officer inform such a driver of the "administrative sanctions that shall be imposed for refusal to take the test." [105] Meanor argued that his BAC test was inadmissible because the police officer failed to inform him of the consequences of not taking the test, in light of Maryland's new interlock program. [106] Meanor challenged the admissibility of his test results because the arresting officer informed him only of the mandatory license suspension and not the possibility of obtaining an interlock-restricted license. [107] In rejecting his argument, the Meanor court relied on an earlier opinion defining a "sanction" as "an outcome that is certain to happen." [108] Since a driver's eligibility to participate in the interlock program is subject to the discretion of the motor vehicle administration, an interlock-restricted license is not a "sanction" under Maryland law. [109] Consequently, the court held that the state's new interlock law had no effect on the advice an arresting officer must give a DUI driver regarding refusal to take a BAC test. [110]

\section{Challenging Interlock Statutes: A Lost Cause?}

How is it that not a single state's ignition interlock program has been successfully challenged? Perhaps it is simply because challenging the statute would do more harm to the recidivist DUI driver than good. Having a driver's license is a privilege, not a right. [111] As such, state legislatures have broad authority in fashioning remedies to the problem of drunk drivers. These include seizure of the vehicle, suspension or even permanent revocation of the driver's license, and, today, requiring the driver to install an ignition interlock in his vehicle. In many ways, a court order to install an ignition interlock is the DUI driver's best alternative. 
This part examines some of the reasons why a DUI driver is unlikely to challenge an interlock statute by reviewing some of the alternative remedies state courts have in dealing with drunk drivers. To argue against an order to install an interlock is equivalent to arguing for total revocation of driving privileges or even seizure of the driver's vehicle. This part concludes by examining whether a constitutional challenge is appropriate, should a driver wish to challenge an interlock statute.

\section{A. Fate Worse than Interlocks: Vehicle Forfeiture}

Thirty-three states authorize seizure of the vehicles of repeat DUI offenders. [112] New York City has even taken the draconian step of seizing the vehicles of first-time offenders. [113] A first-time offender unsuccessfully challenged this policy in Grinberg v. Safir. [114]

On February 21, 1999, a police officer arrested Grinberg for driving while intoxicated following a traffic stop. [115] Police administered a sobriety test, which indicated a BAC of 0.11, and they seized Grinberg's vehicle for forfeiture, pursuant to New York City Code ("NYC Code”). [116] NYC Code directs that property "suspected of being used as a means of committing crime or employed in aid or furtherance of crime...shall be given "into the custody of the Police Department property clerk." [117] In denying Grinberg's petition for the return of the vehicle, the court upheld the forfeiture, despite the lack of a pre-seizure hearing or a criminal conviction. [118] "A drunk diver's automobile is the quintessential instrumentality of a crime "the sine qua non without which the crime could not have been committed." [119] The court dispatched with Grinberg's claim that due process requires a pre-seizure hearing by relying on criteria set forth by the Supreme Court in Calero-Toledo v. Pearson Yacht Leasing Co., 416 U.S. 663 (1974). [120]

In Calero-Toledo, Puerto Rican authorities seized a leased yacht for transporting marijuana. [121] The court found pre-hearing seizure justified for two reasons. First, the Calero-Toledo Court viewed the government's interest in preventing the continued illicit use of property as sufficiently important to require prompt action. [122] Second, the court reasoned that movable property like a boat might be easily secreted to another jurisdiction if the government gave advance warning of seizure. [123] That the owner of the property had no culpability was irrelevant to the court. [124] The Calero-Toledo Court conceded that the lessor of the yacht was completely uninvolved with the lessee's crimes. [125] However, the court considered it settled law, since the time of the Old Testament that no innocent owner defense exists for forfeiture. [126] The court grounded this holding on the notion that the property itself is the offender, not the owner. [127]

Based on these considerations, the New York court in Grinberg denied the firsttime DUI driver's petition for the return of his forfeited vehicle, despite the absence of a pre-seizure hearing or a criminal conviction. [128] In affirming this harsh result, the court noted several factors that militate against property being wrongfully seized. First, the arresting officers are not creditors, therefore, they have no economic incentive to seize a 
vehicle. [129] In addition, because DUI is necessarily an offense committed in the presence of the arresting officer, the heightened probable cause standard for arrest controls the officer's actions. [130] Finally, the results of the blood alcohol test provide added indicia of reliability. [131] While commentators have harshly criticized vehicle forfeiture of first time DUI offenders, [132] forfeiture for recidivist offenders generates much less debate. [133] Furthermore, any chance of the Supreme Court adopting a more restrictive view towards contraband forfeitures is unlikely given its recent decision in Florida v. White. [134] In White, the Court upheld seizure of an automobile used to deliver cocaine, even though the seizure occurred months later, when the owner was arrested on unrelated charges. [135] Seizure of a DUI offender's vehicle remains a firmly established remedy available to the state. [136]

\section{B. Constitutional Challenges}

A DUI driver required to install an ignition interlock is free to assert an equal protection challenge to the court's order. Possible grounds include unjust discrimination against recidivist DUI drivers, alcoholics, or maybe the poor. A constitutional challenge to an interlock statute faces a steep uphill battle because having a driver's license is not a fundamental right and because of the judicial deference generally accorded public welfare and social legislation. This section reviews constitutional challenges to interlock statutes.

The Supreme Court reviewed its three-tiered approach to equal protection cases in City of Cleburne v. Cleburne Living Center, 473 U.S. 432 (1985). The Equal Protection Clause of the Fourteenth Amendment [137] requires that "all persons similarly situated should be treated alike." [138] "The general rule is that legislation is presumed valid and will be sustained if the classification drawn by the statute is rationally related to a legitimate state interest." [139] This rule yields to a much tougher standard of "strict scrutiny" when the classification seldom relates to any legitimate state interest. [140] For example, distinctions based on "race, alienage, or national origin" are immediately suspect as their basis is usually prejudice. [141] The same standard of strict scrutiny also applies when the state law infringes upon a fundamental right secured by the Constitution. [142] In these situations, the need for judicial intervention is more urgent, and the court will act unless the state shows that its law is narrowly tailored to address a compelling state interest. [143] Between theses two levels of scrutiny is a heightened standard of review when the disputed classification "generally provides no sensible ground for differential treatment." [144] When the classification concerns gender or illegitimacy, which are unrelated to a person's "ability to perform or contribute to society," the "classification fails unless it is substantially related to a sufficiently important governmental interest." [145]

As discussed supra, the Supreme Court of Iowa in Pottawattamie County rejected an equal protection challenge by holding that its legislature could rationally discriminate between persons having different prior convictions in determining eligibility for the interlock program. [146] 
The Supreme Court of Wisconsin likewise rejected an equal protect challenge from a hearing impaired driver who claimed that non-hearing impaired drivers better understand the cautionary instructions police give regarding refusal to take a blood alcohol test. [147] The court rejected the assertion that the state needed to provide a certified sign-language expert to communicate the instructions. [148] It held that the officer needed only to make a reasonable accommodation for the hearing impaired driver, such as communicating in writing. [149]

While no person has yet raised an interlock challenge on the basis that it discriminates against alcoholics, such a claim would likely fail. Federal courts of appeal have decisively held that alcoholism is not a suspect or quasi-suspect classification, therefore, laws regulating access to government benefits for alcoholics need only satisfy the lowest level of scrutiny, a rational basis test. [150] Given this result, an equal protection challenge based on alcoholism would likely fail because the interlock statute rationally relates to the legitimate governmental interest of promoting highway safety.

Equal protection challenges based on age, such as special penalties for offenders under the age of 21, [151] or wealth would face a rational basis test, since neither age [152] nor wealth [153] is a suspect or quasi-suspect classification. That wealth is not a suspect classification is particularly important because it means poverty, or inability to afford the interlock, is unlikely to be the basis of a successful constitutional challenge. While this may seem like a harsh result, it is far less oppressive than outright forfeiture of the vehicle, a legally sanctioned remedy.

Constitutional challenges based on other strategies would be equally difficult to sustain since operating a motor vehicle is not a fundamental right. [154] The Supreme Court made this clear in Mackey v. Montrym wherein it upheld a Massachusetts statute summarily requiring license suspension for refusing to submit to a blood alcohol test upon arrest for DUI. [155] While the Court recognized that a driver's license embodies a property interest sufficient to raise Due Process concerns, it ruled that the state interest in protecting public safety is paramount. [156] Central to the Mackey Court's reasoning was that refusing to take a blood alcohol test is such an unambiguous and verifiable event that the risk of error is minimal, particularly given the probable cause hurdle required for the arrest. [157] For the Mackey Court, the likelihood of an officer deliberately fabricating facts or misinterpreting intoxication is "insubstantial." [158] Recognizing the need for the state to remove drunk drivers from the road at "the earliest possible moment," the Court held that the state could properly dispense with a pre-seizure hearing. [159] As for protecting the driver's interests, the Court found that a "prompt post deprivation review" was adequate. [160]

\section{A Universal Interlock Program}

This part examines the consequences of universal interlock installation. It begins with a look at the motivations and the benefits for using such a mechanism. Next, it frankly examines several privacy and liability concerns that should be addressed in order 
for such a program to gain widespread support. Finally, it concludes with several recommendations aimed at addressing these concerns.

\section{A. The Benefits}

Each year there are approximately 16,000 alcohol-related fatalities on America's highways. [161] In 1999, someone died in an alcohol-related crash every 33 minutes.161a In 1998, there were 16,189 alcohol-related highway fatalities.161b In 78\% of those cases, the deceased was legally intoxicated. [162] Alcohol-related, fatal traffic accidents cost Americans a staggering \$50 billion annually in medical expenses, property damage, lost productivity, and other expenses. [163] If a universal interlock program targeted only legally intoxicated drivers, up to 12,000 lives and $\$ 40$ billion could be saved annually. [164]

In order to put this number of saved lives in perspective, consider the benefits of air bags. Air bags first became standard equipment in the 1985 model year. [165] Since the 1999 model year, all cars and light trucks were required to have dual air bags, although the majority of all new vehicles already had dual air bags by the 1995 model year. [166] While air bags are considered highly effective in reducing fatalities, the overall number of lives saved by air bags pales in comparison to what could be achieved with interlocks.

During the period between 1986 and March 1, 2000, air bags have saved 5,303 lives. [167] If all vehicles on the road had dual air bags, NHTSA estimates that they would save up to 3,200 lives annually. [168] Unfortunately, the efficacy of air bags is highly dependent on the use of seat belts, and the NHTSA estimate assumes $100 \%$ seat belt usage. [169] Given that the actual seat belt usage rate is 67\%, the number of potential lives saved annually could drop to as low as 1,600. [170] These figures show that the maximum number of lives saved by installing air bags is only one-tenth the 16,000 lives that could potentially be saved with interlocks. Even seat belts, which are practically the sine qua non of motor vehicle safety, save only an estimated 9,500 lives a year, [171] just a fraction of the potential number of lives saved by installing interlocks.

With statistics like these, Congress will likely take a hard look at requiring an alcohol ignition interlock in every vehicle. Before this bandwagon gains too much momentum, a look at some drawbacks of an interlock program is in order.

\section{B. Universal Interlocks: A Plaintiff 's Best Friend?}

Few people could probably say that they have never gotten behind the wheel of a car after taking a drink. Unfortunately for the defendant, his interlock companion will be recording every sip for the plaintiff's attorney to present to the jury.

A BAC of 0.10 is sufficient for a DUI conviction in all fifty states, but actual impairment occurs at much lower levels. A recent NHTSA-sponsored study showed that some impairment begins at only 0.02. [172] A major finding of the study was that a BAC 
of only 0.04 degrades driving performance by every measure of impairment. [173] The report concludes by noting that there is no scientific evidence to suggest that there is any impairment-free blood alcohol concentration. [174] Based on these results, one could argue that a person is negligent for driving after taking even a single drink, although the case is much stronger if the BAC is 0.04.

The pitfalls of having an on-board data recorder in a vehicle, while perhaps not widely recognized, are not new. Last year, the Sixth Circuit Court of Appeals dealt with such an issue in Harris v. General Motors Corporation. [175] In that case, Harris sued General Motors ("GM"), alleging that the air bag of her vehicle deployed as she was reaching for the ignition switch, thereby breaking her arm. [176] Before trial, GM successfully moved for summary judgment using data retrieved from the car's "Diagnostic Energy Reserve Module," or "DERM." [177] In an affidavit, one of GM's engineers used data downloaded from the DERM to refute the plaintiff's version of the events preceding air bag deployment. [178] Although the court of appeals reversed and remanded the case for trial, [179] the case served as notice for trial attorneys that a new vehicle crash data battle is looming. [180]

While most plaintiff attorneys do not even know about motor vehicle "black boxes," the devices have been around since 1974, and today GM alone has installed over six million in its vehicles. [181] The reason for these devices is perfectly logical. Manufacturer's need crash data to improve vehicle safety, particularly for improving air bags. [182] This work has received the active encouragement of the National Transportation Safety Board as well as the NHTSA. [183] Today's black boxes record over a dozen vehicle parameters including: air bag status, seat belt status, engine speed, vehicle speed, brake status, and throttle position. [184] While the intentions behind these devices are laudable, their praise has not been universal. [185]

Obtaining the stored crash data requires a proprietary data decoder. [186] In some situations, manufacturers have denied crash victims access to this data. [187] Since the vehicle owner is incapable of retrieving the data, he is unable to ensure that the data, once made available, is unaltered. [188] Finally, an expert is necessary to interpret the data, which may present a formidable challenge when suing an automaker. [189]

For alcohol ignition interlocks to gain widespread support, people will need assurance that their interlock-equipped vehicle will not drive them to financial ruin. While there has not been much of an outcry over vehicle "black boxes," the ones that monitor many parameters have only been around since 1999, and most people are unaware of their existence. However, other high-tech, vehicle-monitoring gadgets have generated significant controversy.

One case in point is cameras that automatically ticket drivers who run red lights at intersections. Since San Diego installed such a system three years ago, the city has issued 84,000 tickets averaging \$271 each. [190] Advocates of the program have dismissed their opponents as "politicians with a Libertarian bent." [191] However, the Los Angeles Times reported that a camera sensor defect has resulted in the suspension of 
the program and the "dismissal of hundreds of traffic citations." [192] Even the city's police union joined the chorus of opponents after five on-duty officers received fines. [193]

As technology advances so does the ability to monitor driver behavior. AirIQ, Inc. markets a vehicle monitoring system that uses a satellite Global Positioning System (GPS) to track a vehicle's location to within 100 yards. [194] By coupling the GPS with an on-board data recorder, AirIQ's device enables someone to retrieve a report documenting a vehicle's location, speed, and direction in five-minute intervals. [195] AirIQ's website touts its system as being able to locate overdue vehicles, enforce geographical driver restrictions, and monitor driver behavior. It even boasts that the AirIQ system can disable a stolen vehicle with the "click of a mouse." [196] Such powerful technology has come to the attention of owners of large commercial rental fleets.

Using this technology, Budget Rent a Car readily found one of its cars, due in at a California franchise, across the country in Louisiana. [197] The Thrifty Rental Company learned that one of its customers was speeding at $100 \mathrm{mph}$ before having an accident. [198] Budget Rent a Car Corp. is also using vehicle-monitoring technology, purportedly to prevent theft, although a company spokeswoman could not "speak for the individual franchises and how they use the system." [199] In perhaps the ultimate marriage of technology with corporate hubris, Acme Rent-a-Car in New Haven, Connecticut uses AirIQ's equipment to automatically fine its customer's \$150 each time they exceed the speed limit. [200] One unfortunate lessee missed this provision in the rental agreement and became aware of it only after his credit card issuer froze his account because of three successive $\$ 150$ debits. [201] The Connecticut Department of Consumer Protection has since joined Acme's hasty customer in his legal action against Acme Rent-a-Car. [202]

\section{Guidelines: Protecting Privacy and Avoiding Crippling Liability}

People do not like being treated like criminals. How will the average driver feel about having to prove that he is not violating a DUI law every time he uses his vehicle? Steven Wisotsky, in an article for Cato Research Ltd., decried America's "war on drugs" as turning our country into a "society of suspects." [203] He cites specific examples of how the war-like, get-tough, "crackdown mentality" is permeating our criminal justice system.203a To demonstrate this, Wisotsky lists such war-like measures as the kidnapping of persons from foreign countries to stand trial on drug charges in the United States, body cavity searches by customs agents, and mandatory life sentences for firsttime drug offenders. [204] To Mr. Wisotsky, these measures are evidence that there now exists a "drug exception" to the Bill of Rights. [205]

Interlock advocates may best serve their cause by refraining from drawing analogies with the United States' controversial war on drugs. They should recognize that just as there is certainly no drug exception to the Bill of Rights, neither is there a drunk driving exception. Proponents of universal interlock programs should adopt some clear privacy safeguards along with their interlock advocacy. Furthermore, few people will 
likely support ignition interlocks if taking a single drink automatically exposes them to crippling civil liability. This subsection proposes a few such safeguards.

One way to safeguard the public is to remove the data recording capability from the interlock. While this feature is necessary to monitor a DUI offender's compliance with the conditions of her probation, it serves no useful purpose for the general population. Checking for attempts to disable the system could be part of an annual vehicle inspection. Only the DUI offender should suffer much more invasive driver monitoring technology. [206]

From time to time, a non-DUI offender will operate a vehicle having full data recording features. Perhaps he will borrow the car of an offender or rent a commercial vehicle having extensive driver monitoring capabilities. In these situations, statutory safeguards are necessary. Thanks to existing DUI laws such provisions are already in place. As an example, a subsection of Pennsylvania's DUI statute provides the following:[207]

(d) Presumptions from amount of alcohol.--If chemical testing of a person's breath, blood or urine shows:

(1) That the amount of alcohol by weight in the blood of an adult is $0.05 \%$ or less, it shall be presumed that the adult was not under the influence of alcohol and the adult shall not be charged with any violation under section 3731(a)(1), (4) or (5) (relating to driving under influence of alcohol or controlled substance), or, if the adult was so charged prior to the test, the charge shall be void ab initio.

(2) That the amount of alcohol by weight in the blood of an adult is in excess of $0.05 \%$ but less than $0.10 \%$, this fact shall not give rise to any presumption that the adult was or was not under the influence of alcohol, but this fact may be considered with other competent evidence in determining whether the adult was or was not under the influence of alcohol.

Pennsylvania's vehicle code creates an irrefutable statutory presumption that a person with a BAC of 0.05 is not an impaired driver. Admittedly, this presumption conflicts with the medical evidence, which shows that there is some impairment with a BAC as low as 0.02 , but there is a rational basis for it. The legislature balances public safety with the legitimate interest in avoiding vexatious lawsuits. For intermediate blood alcohol levels, the Pennsylvania statute is presumptively neutral. In a civil suit, this places the burden of proof upon the plaintiff to show impairment.

By adopting reasonable measures such as this, a driver will not be blind-sided with a financially ruinous lawsuit for having one or two drinks. In order for a universal interlock program to gain support, certain safeguards are necessary. No person will feel comfortable if his vehicle has the potential to become a plaintiff's star witness. Interlock advocates might best serve their cause by developing clear measures aimed at preserving the privacy of innocent drivers early in their cause. 


\section{Conclusion}

Alcohol ignition interlocks have the potential to achieve something that no governmental agency, health care facility, 12-step program, or concerned spouse has accomplished-prevent a person from driving drunk. Thanks to recent advances in technology, circumvention of interlocks is becoming much more difficult. Interlocks offer a powerful new option in dealing with the habitual DUI offender. Interlocks are not only constitutionally permissible, but the offender is likely to prefer them to other firmly established remedies such as indefinite license revocation or summary vehicle forfeiture.

Approximately 16,000 people die each year in alcohol-related accidents on the United States' highways. Interlocks have the potential to save more lives annually than seat belts and air bags combined. With these considerations in mind, it is only a matter of time before some form of universal interlock program gains momentum. This raises not only serious privacy concerns, but financial ones as well. No person is likely to support an interlock initiative if he feels spied on or if he might suffer ruinous financial liability. Therefore, carefully crafted statutory safeguards should be the cornerstone of any viable universal interlock program.

[FN1] Nat'l Highway Traffic Safety Admin. Rep. No. DOT HS 809 086, Traffic Safety Facts 1999 - Alcohol. Nat'l Center for Statistics \& Analysis, Research \& Dev., 400 Seventh St., N.W., Washington, D.C. 20590, available at http://www.nhtsa.dot.gov/people/ncsa/factshet.html (visited July 31, 2001).

[FN2] 23 U.S.C.A. § 154, 164; 38 U.S.C.A. § 1103 (West, WESTLAW through P.L. 107-11, May 28, 2001).

[FN3] 23 U.S.C.A. § 164(a)(5)(B).

[FN4] See, e.g., 42 Pa. Con. Stat. Ann. § 7001 (West WESTLAW through 2000 Reg. Sess.). Pennsylvania's lockout level is $0.025 \%$. Id.

[FN5] In Pennsylvania, an interlock is available from Interlock Installation Services, Ltd., which charges $\$ 75$ to install the device and $\$ 75 /$ month rent, available at http://www.sobersense.com (visited June 6/29/2001). Another company, Sens-O-Lock Distribution of New England, Ltd., charges a \$65/month rental fee, and it sells a unit for \$795, available at http://www.sens-o-lock.com/webpages/faq_car.-html (visited August 10, 2001).

[FN6] Douglas J. Beirness, Best Practices for Alcohol Interlock Programs passim (The Traffic Injury Research Foundation, Ottawa, Ontario, April 2001), available at http://www.trafficinjuryresearch.com/ publications (visited July 3, 2001).

[FN7] DUI, or driving under the influence, and DWI, driving while intoxicated, means driving with a blood alcohol level over the statutory limit. DUI, as used in this comment, refers strictly to driving under the influence of alcohol, although many of the statutes 
discussed here also criminalize driving under the influence of a controlled substance. See, e.g., Driving Under the Influence of Alcohol or a Controlled Substance, $75 \mathrm{~Pa}$. Con. Stat. Ann. § 3731 (West 2001). For convenience to the reader, the term "DUI" is used throughout this comment, even when discussing states wherein the charge is DWI.

[FN8] 23 U.S.C.A § 164(a)(5)(B) (West 2001).

[FN9] Repeat Intoxicated Driver Laws, 65 Fed. Reg. 59112, 59117 (2000) (to be codified at 23 C.F.R. pt. 1275).

[FN10] See, e.g., Mothers Against Drunk Driving “MADD,” Public Policy Position Statements, available at http://www.madd.org/pub_pol/positions_sanctions.shtml (visited July 28, 2001); National Commission Against Drunk Driving “NCADD,” available at http://www.ncadd.com/tsra/abstracts/025.html (visited July 28, 2001), (summarizing Barbara J. Morse and Delbert S. Elliot, Effects of Ignition Interlock Devices on DUI Recidivism: Findings from a Longitudinal Study in Hamilton County, Ohio, 38(2) Crime and Delinquency 131-57 (1992)).

[FN11] See, e.g., Judge William J. Caprathe, Alcohol Related Driver’s License Suspensions-Five Concepts to Consider Before Restoration, 76 Mich. B.J. 282 (1997). "I believe that our roads would be much safer if everyone convicted of drinking and driving were required to have an interlock for at least six months." Id. at 285.

[FN12] Nat'l Highway Traffic Safety Admin., Vehicle and License Plate Sanctions, available at http://www.nhtsa.dot.gov/people/outreach/stateleg/velegislative.html (visited July 28, 2001).

Forty-three states have laws providing for either the discretionary or mandatory use of ignition interlock devices for repeat and chronic DWI offenders. The ignition interlock is discretionary in the following states: Alaska, Arkansas, Delaware, Florida, Georgia, Illinois, Indiana, Kansas, Kentucky, Maine, Maryland, Michigan, Minnesota, Mississippi, Montana, Nebraska, Nevada, New Hampshire, New Mexico, New York, North Carolina, North Dakota, Ohio, Pennsylvania, Rhode Island, South Carolina, Tennessee, West Virginia, and Wisconsin. In fourteen states, the law is mandatory under some special circumstances. Those mandatory state are: Arizona, California, Colorado, Idaho, Iowa, New Jersey, Oklahoma, Missouri, Oregon, Texas, Utah, Virginia, and Washington. Id.

[FN13] 18 Pa. Con. Stat. Ann. § 7514, 42 Pa. Con. Stat. Ann. § 7001-03 (West WESTLAW through 2000 Reg. Sess.).

[FN14] Beirness, supra note 6, at 45.

[FN15] H. Moskowitz et al., Driver Characteristics and Impairment at Various BACs 1 n.1 (Nat'l Highway Traffic Safety Admin., Washington, D.C. August 2000), available at http://www.nhtsa.dot.gov/people/outreach/media/publications (visited July 28, 2001). Court decisions and the literature on driver intoxication frequently dispense with the percent symbol when reporting BAC. See, e.g., the source cited infra note 17. 
[FN16] H. Moskowitz et al., supra note 15, at 1.

[FN17] Robert Apsler, Ph.D., et al., The Effects of 0.08 BAC Laws 1 n.1 (Nat'l Highway Traffic Safety Admin., Washington, D.C. April 1999). One using percent to measure BAC is actually employing a dimensional slight-of-hand. Clearly, dividing 0.1 grams by $100 \mathrm{ml}$ yields a result having the unit $\mathrm{g} / \mathrm{ml}$, not percent, available at http://www.nhtsa.dot.gov/people/outreach/media/publications (visited July 28, 2001).

[FN18] H. Moskowitz et al., supra note 15, at 1.

[FN19] Id. At least 28 states have adopted the lower 0.08\% BAC limit. Matt Stearns, Lower Limit for Alcohol Becomes Law; Signing Frees Highway Funds for Missouri, Kansas City Star, June 13, 2001, at A1. The article notes that there has been a recent rush among the states to adopt the $0.08 \%$ limit, thanks to a federal highway funding incentive enacted June 9, 1998. See 23 U.S.C.A. § 163 (West, WESTLAW through P.L. 107-11, May 28, 2001).

[FN20] Model Specifications for Breath Alcohol Ignition Interlock Devices (BAIIDs), 57 Fed. Reg. 11,772, 11,782 (1992). Although not widely used as interlocks, other alcohol sensing technology exists. Some devices require that the driver quickly perform a task requiring a high degree of psychomotor dexterity. E. Donald Sussman, et al., Condition Responsive Control Apparatus, U.S. Patent No. 3,886,540 (issued May 27, 1975). A much newer device uses a spectroscopic technique to non-invasively measure BAC based on the alcohol-dependent optical absorption characteristics of tissue. Steven Steinberg, Non-Invasive Optical Blood Alcohol Concentration Reader and Vehicle Ignition Interlock and Method, U.S. Patent No. 5,743,349 (issued April 28, 1998).

[FN21] Beirness, supra note 6, at 8 . The literature frequently uses the term "fuel cell" for the electrochemical sensor. See, e.g., Id.

[FN22] Verne R. Brown, Breath Alcohol Detector and Automotive Ignition Interlock Employing Same, U.S. Patent No. 3,780,311, col. 1, (issued Dec. 18, 1973).

[FN23] Beirness, supra note 6, at 8.

[FN24] Id.

[FN25] Brown, supra note 22; Beirness, supra note 6, at 8.

[FN26] Beirness, supra note 6, at 8; Timothy J. Prachar et al., Breath Analyzer for Use In Automobile Ignition Locking Systems, U.S. Patent No. 5,426,415, col. 1, (issued June 20, 1995). See also Anthony Porter et al., Vehicle Breath Monitoring Device, U.S. Patent No. 4,926,164 (issued May 15, 1990).

[FN27] Beirness, supra note 6, at 9. 
[FN28] Id.

[FN29] Id.

[FN30] Id.

[FN31] Id.

[FN32] Model Specifications for Breath Alcohol Ignition Interlock Devices (BAIIDs), 57

Fed. Reg. at 11,781. California has specified a cutoff of $0.03 \%$, New York $0.02 \%$. Id.

Pennsylvania's cutoff level is 0.025\%. See 31 Pa. Bull. 3369 (June 23, 2001).

[FN33] Model Specifications for Breath Alcohol Ignition Interlock Devices (BAIIDs), 57 Fed. Reg. at 11,781.

[FN34] Beirness, supra note 6, at 10. Simple devices exist to ensure that the driver is not using an air-filled balloon or some other compressed air source. One system requires the driver to modulate her breath in response to an audible or visual signal in such a manner as to decrease the likelihood that the air is from a non-human source. Achille M.

Bigliardi, Vehicular Ignition Interlock System, U.S. Patent No. 5,020,628 (issued June 4, 1991).

[FN35] Beirness, supra note 6, at 10.

[FN36] Id.

[FN37] Model Specifications for Breath Alcohol Ignition Interlock Devices (BAIIDs), 57 Fed. Reg. at 11,779.

[FN38] Beirness, supra note 6, at 10.

[FN39] Model Specifications for Breath Alcohol Ignition Interlock Devices (BAIIDs), 57 Fed. Reg. at 11,779.

[FN40] Id. "Only the rolling retest appears to provide a method for controlling such illicit assistance curbside, at least until the time that manufacturers develop some more economical method for identifying the individual providing the sample for test." Id. Although perhaps not commercially feasible, identification technology certainly exists. See e.g., Collier et al., Sobriety Interlock with Unsupervised Confirmation of Operator Identity, U.S. Patent No. 4,738,333 (issued April 19, 1988).

[FN41] Model Specifications for Breath Alcohol Ignition Interlock Devices (BAIIDs), 57 Fed. Reg. at 11,773.

[FN42] Id.; Beirness, supra note 6, at 11. 
[FN43] Beirness, supra note 6, at 65.

[FN44] Model Specifications for Breath Alcohol Ignition Interlock Devices (BAIIDs), 57 Fed. Reg. at 11,782.

[FN45] See 23 U.S.C.A. §§ 154, 164; 38 U.S.C.A. § 1103; Repeat Intoxicated Driver Laws, 65 Fed. Reg. at 59,112. The TEA 21 Restoration Act restored provisions inadvertently omitted from TEA 21, which was signed into law on June 9, 1998. Repeat Intoxicated Driver Laws, 65 Fed. Reg. at 59,112. 23 U.S.C. $§ 164$ calls for the transfer of 1.5 percent of the authorized $\S 104$ funds in fiscal years 2001 and 2002. 23 U.S.C.A. \$164(b)(1). Commencing in fiscal year 2003 and in all years thereafter, 3 percent of the authorized § 104 funding shall be transferred to 23 U.S.C. § 402 safety programs. Id. at § 164(b)(2).

[FN46] Repeat Intoxicated Driver Laws, 65 Fed. Reg. at 59112.

[FN47] 23 U.S.C.A. §164(a)(5).

[FN48] 23 U.S.C.A. §164(a)(5)(A).

[FN49] 23 U.S.C.A. §164(a)(5)(B). NHSTA, in its rules implementing § 164, noted that the timing of the interlock sanction generated considerable controversy. Repeat Intoxicated Driver Laws, 65 Fed. Reg. at 59117. NHSTA reported that as many as 70\% of repeat offenders continue to drive during license suspension. Therefore, interlocks are most effective when installed immediately after arrest, license suspension notwithstanding. NHSTA declined to adopt a rule requiring interlock installation immediately upon arrest, however. It felt that since $\S 164$ was silent regarding the timing of the sanctions, NHSTA had best not promulgate that states require an offender to install an interlock at the same time it also suspends his license. NHSTA recognized interlocks are a novel approach to an extremely complex problem. Therefore, in the absence of congressional direction, it concluded that the states require maximum flexibility in determining the appropriate timing of the interlock requirement. Id. at 59,117-19.

[FN50] 23 U.S.C.A. \$164(a)(5)(C).

[FN51] 23 U.S.C.A. \$164(a)(5)(D). The offender must perform not less than 30 days of community service or serve not less than 5 days of imprisonment for a second conviction. Id. Third or subsequent offenders must suffer not less than 60 days of community service or not less than 10 days of imprisonment. Id.

[FN52] See 23 U.S.C.A. §164(b)(1) (setting forth the Secretary's timetable for making his compliance determination). See also Repeat Intoxicated Driver Laws, 65 Fed. Reg. 59,112 (2000) (to be codified at 23 C.F.R. pt. 1275) (enumerating the rules and regulations promulgated by the Fed. Highway and the Nat'l Highway Safety Admin. for implementing the TEA 21 Restoration Act). 
[FN53] Repeat Intoxicated Driver Laws, 65 Fed. Reg. at 59,119.

[FN54] Supra note 12. At last count, the exact number was 43. Id.

[FN55] 17 N.J. Practice, Municipal Court Practice § 31.28.1 (2nd ed.) (2000 Pocket Part).

[FN56] West's Ann. Cal. Vehicle Code § 23575 (West, WESTLAW through 1st Ex. Sess., Nov. 7. 2000). The court gives heightened consideration to ordering installation when the first offender's BAC is 0.20 , or when a driver refuses a chemical test upon arrest. Id. at §23575(a)(1).

[FN57] West's Ann. Cal. Vehicle Code § 23575(a)(2) (West, WESTLAW through 1st Ex. Sess., Nov. 7. 2000).

[FN58] Cal. Ct. R. 4.325.

[FN59] See Cal. Penal Code §1203.1b (West 2000). “This subdivision does not require any county to pay the costs of purchasing and installing any ignition interlock.... The Office of Traffic Safety shall consult with the presiding judge or his or her designee in each county to determine an appropriate means, if any, to provide for installation of ignition interlock devices in cases in which the defendant has no ability to pay." Id.

[FN60] 17 Cal. Rptr. 2d 462, 466 (1993).

[FN61] 23 Cal. Rptr. 2d 644, 652 (1993).

[FN62] N.Y. Veh. \& Traf. Law § 1198(1 \& 2) (West, chs. 4 to 25). See also 2001 Sess. Law News of N.Y. Ch. 86 (A. 8939) (June 29, 2001) (McKinney's 2001) (amending the expiration date of $\S 1198$ from July 1, 2001 to July 1, 2003).

[FN63] See supra note 49.

[FN64] 86 N.Y.2d 259, 263, 268-69 (1995).

[FN65] Letterlough, 86 N.Y.2d at 261.

[FN66] Id. at 263.

[FN67] Id. at 263, 268.

[FN68] Id.

[FN69] Id. at 268-69.

[FN70] Id. at 269. 
[FN71] See also Bridle v. State, 16 S.W.3d 906, 907 (Tex. Ct. App. 2000); State v. Hansen, 542 N.W.2d 424, 434 (Neb. 1996); State v. Piddington, 623 N.W.2d 528, 535 (Wis. 2001); State v. Proffitt, 930 P.2d 1059, 1062 (Kan. 1997); In re Reese, 495 S.E.2d 548, 549 (W.Va. 1997); Gray v. Admin. Dir. of the Court, State of Haw., 931 P.2d 580, 595 (Hawaii 1997) (affirming lifetime revocation of driver's license). While none of these cases construes the state interlock statute, they at least passively acknowledge its existence.

[FN72] City of Akron v. Kirby, 681 N.E.2d 444, 451 (Ohio App. 1996).

[FN73] Id. at 446.

[FN74] Id.

[FN75] Id.

[FN76] Id. at 451.

[FN77] 714 N.E.2d 902, 904 (Ohio 1999).

[FN78] City of Lakewood, 714 N.E.2d at 903-04. The driver had four prior DUI convictions and eight prior convictions for driving with a suspended license in the previous four years. Id. At the time of her arrest, the defendant actually had conditional driving privileges. She could drive for "occupational, grocery, medical, and day care purposes, and AA meetings.” Id.

[FN79] See Ohio Statute § 2951.02(G) (Baldwin, WESTLAW through 124th G.A., 2001 Files 1 to 3, apv. 3/30/01). While the statute enables courts to order an interlock as a DUI probation condition, the statute is silent on whether the courts may do the same for driving with a suspended license, where the reason for the suspension is a prior DUI conviction.

[FN80] Supra note 64.

[FN81] City of Lakewood, 714 N.E.2d at 904. Ohio's catch-all probation provision provides the following:

In determining whether to suspend a sentence of imprisonment upon an offender for a misdemeanor and place the offender on probation ..., the court shall consider the risk that the offender will commit another offense and the need for protecting the public from the risk, the nature and circumstances of the offense, and the history, character, and condition of the offender. Id.

[FN82] Id.

[FN83] Id. 
[FN84] Id.

[FN85] Id.

[FN86] City of Lakewood, 714 N.E.2d at 904.

[FN87] 592 N.W.2d 41 (Iowa 1999).

[FN88] Pottawattamie County, 592 N.W.2d at 42.

[FN89] Iowa Statute § 321.J4 (West, WESTLAW through 2000 Reg. Sess.).

[FN90] Iowa Statute § 321.555 .

[FN91] Id. The offenses include manslaughter with a motor vehicle, DUI, driving with a suspended license, perjury to the department of public safety, using a motor vehicle in the commission of a felony, failure to stop or leave information relating to an accident, eluding a pursuing law enforcement vehicle, or serious injury by vehicle. Id. at $\S$ 321.555(1).

[FN92] Pottawattamie County, 592 N.W.2d at 44.

[FN93] Id.

[FN94] Id.

[FN95] Id. at 42.

[FN96] Id.

[FN97] Pottawattamie County, 592 N.W.2d at 43. The court noted that a driver's license is a statutorily created privilege, not a constitutional right. Id. at 44 .

[FN98] Id. at 43.

[FN99] Id.

[FN100] Id.

[FN101] Id. at 45. (emphasis in original).

The purpose of the habitual offender statue is to protect the public from drivers who refuse to observe the rules of prudence and safety. The legislature could have reasoned that a person with the propensity to habitually commit multiple different crimes is a more serious type of habitual offender, has a greater detrimental impact upon society, and is less deserving of the privilege of a temporary restricted license. Id. 
[FN102] See also Collins v. Department of Public Safety, 991 P.2d 557 (Ok. Civ. App. 1999) (applying the rational basis test in upholding an equal protection challenge to 1)

Oklahoma's DUI statute restricting BAC to zero for drivers under 21 years of age, and 2) a court ordered interlock for such a driver)).

[FN103] Md. Code Ann. § 16-404.1 (2000).

[FN104] 774 A.2d 394, 395 (Md. 2001).

[FN105] Md. Code Ann. § 16-205.1 (2000).

[FN106] Meanor, 774 A.2d at 396.

[FN107] Id.

[FN108] Id. at 405 (citing Motor Vehicle Admin. v. Chamberlain, 604 A.2d 919, 925 (Md. 1992)).

[FN109] Id. at 406.

[FN110] Id.

[FN111] See Pottawattamie County, 592 N.W.2d at 44 (noting that a recidivist DUI offender's eligibility for a restricted license is "not a constitutional right, but a statutory privilege granted by the legislature"). See also Frantz v. Dept. of Transp., Bureau of Driver Licensing, 649 A.2d 148 (Pa. Commw. Ct. 1994). "The privilege to operate a motor vehicle is not a fundamental right." Id. at 151.

[FN112] Douglas A. Terry, Take a Drink, Lose A Car: The Constitutionality of the New York City Forfeiture Policy As Applied to First-Time DWI Offenders, In the Wake Of Recent Excessive Fines and Double Jeopardy Clause Jurisprudence, 61 OHIO STATE L.J. 1793, 1795 (2000).

[FN113] Id.

[FN114] 694 N.Y.S.2d 316 (N.Y. Sup. Ct. 1999), aff'd, 698 N.Y.S.2d 219 (N.Y. App. Div. 1999), appeal dismissed, 94 N.Y.2d 898 (2000).

[FN115] Grinberg, 694 N.Y.S.2d at 319-20.

[FN116] Id. at 320.

[FN117] Id. (quoting New York City, N.Y., Code § 14-140(4)(b) (West, WESTLAW through Local Law 74 of 2000 and chapter 609 of the Laws of New York for 2000). 
[FN118] Id. at 324.

[FN119] Id. at 320. The court recalled other vehicle forfeitures that have been upheld, such as using a car to patronize a prostitute. Id. "Just because one can buy contraband or patronize a prostitute without a car does not alter the vehicle's nature as an instrumentality subject to forfeiture.” Id. Such a view comports well with the recent decisions of the Supreme Court. See Bennis v. Michigan, 516 U.S. 442 (1996) (upholding Michigan Supreme Court decision denying wife and co-owner of vehicle an "innocent owner" recovery claim when husband's patronage of a prostitute caused car's forfeiture under Michigan’s indecency law).

[FN120] Grinberg, 694 N.Y.S.2d at 325.

[FN121] Calero-Toledo, 416 U.S. at 665.

[FN122] Id. at 679.

[FN123] Id.

[FN124] Id. at 668.

[FN125] Id.

[FN126] Calero-Toledo, 416 U.S. at 686.

[FN127] Id. at 684-86. "If an ox gore a man or a woman, and they die, he shall be stoned and his flesh shall not be eaten." (citing Exodus 21:28 to show that an innocent owner suffers the punishment for the injury caused by his property). Id. at 680-81 \& n.17.

[FN128] Grinberg, 694 N.Y.S.2d at 325-26.

[FN129] Id. at 325.

[FN130] Id.

[FN131] Id.

[FN132] Terry, supra note 112.

[FN133] See e.g., City of Akron, 681 N.E.2d at 447-489, appeal dismissed, 687 N.E.2d 576 (Ohio 1996) (citing Akron City Code requiring arresting officer to seize a DUI driver's vehicle when driver has a prior conviction, without regard to actual ownership); State v. Piddington, 623 N.W.2d 528, 535 (Wis. 2001) (citing Wisconsin statue authorizing seizure and forfeiture if driver has two or more prior DUI convictions). See also Commonwealth v. Crosby, 568 A.2d 233, 238 (Pa. Super. 1990) (affirming, in part, 
a trial judge's sua sponte forfeiture order of multiple DUI driver's truck as a condition of probation under common law doctrine of forfeiture of contraband); but see CaleroToledo, 416 U.S. at 678 (upholding forfeiture "under the standards of a narrowly drawn statute”) (citing Fuentes v. Shevin, 407 U.S. 67, 91 (1972)).

[FN134] 526 U.S. 559 (1999).

[FN135] White, 526 U.S. at 561.

[FN136] Another remedy available to the state is lifetime revocation of the DUI offender's license. At least one state supreme court assented to this course in Gray v. Admin. Dir. of the Court, State of Haw., 931 P.2d 580 (Hawaii 1997). See also Dixon v. Love, 431 U.S. 105 (1977) (upholding Illinois statute providing for summary revocation of a driver's license for an indefinite term without any prior hearing).

[FN137] "No State shall make or enforce any law which shall...deny to any person within its jurisdiction the equal protection of the laws." U.S. CONST. AMEND. XIV $\S 1$.

[FN138] City of Cleburne, 473 U.S. at 439.

[FN139] Id. at 440.

[FN140] Id.

[FN141] Id.

[FN142] Id.

[FN143] City of Cleburne, 473 U.S. at 440.

[FN144] Id.

[FN145] Id. at 441.

[FN146] Pottawattamie County, 592 N.W.2d at 45.

[FN147] Piddington, 623 N.W.2d at 546.

[FN148] Id. at 548.

[FN149] Id.

[FN150] Ball v. Massanari, 254 F.3d 817, 824 (9th Cir. 2001); Mitchell v. Commissioner of the Soc. Sec. Admin., 182 F.3d 272, 274 (4th Cir. 1999), cert. denied 528 U.S. 944 (1999); Gazette v. City of Pontiac, 41 F.3d 1061, 1067 (6th Cir. 1994) (citing City of Cleburne, 473 U.S. at 445-46). 
[FN151] See supra text accompanying note 102.

[FN152] Massachusetts Bd. of Ret. v. Murgia, 427 U.S. 307, 312-13 (1976) (per curiam); Gregory T. Neugebauer, A Federal Age Discrimination Remedy Violates State Eleventh Amendment Immunity: Kimel v. Florida Board of Regents, 39 DuQ. LAW REv. 243, 26162 (2000).

[FN153] Harris v. McRae, 448 U.S. 297, 322-23 (1980).

[FN154] Frantz, 649 A.2d at 151 (citing Mackey v. Montrym, 443 U.S. 1 (1979)).

[FN155] 443 U.S. 1, 19 (1979).

[FN156] Mackey, 443 U.S. at 11, 18. The court also noted that the summary suspension process itself is a deterrent to drunk driving. Id. at 18.

[FN157] Id. at 14. Massachusetts required that two officers witness the refusal. Id.

[FN158] Id.

[FN159] Id. at 15.

[FN160] Id. at 12-13. Length of the suspension was not a factor in the Mackey Court's decision. It pointed out that it had upheld a similar statute in Dixon v. Love, 431 U.S. 105 (1977) that provided for a summary revocation of indefinite term. Mackey, 443 U.S. at 12.

[FN161] Repeat Intoxicated Driver Laws, 65 Fed. Reg. 59,112(I)(a) (October 4, 2000) (to be codified at 23 C.F.R. pt. 1275).

[FN161a] Id.

[FN161b] The World ALMANAC AND BOOK OF FACTS 2000, 895 (Robert Famighetti ed., 1999).

[FN162] THE WORLD ALMANAC, supra note 161b, at 895.

[FN163] Repeat Intoxicated Driver Laws, 65 Fed. Reg. 59,112 (October 4, 2000) (to be codified at 23 C.F.R. pt. 1275).

[FN164] 78\% of 16,000 and $\$ 50$ billion.

[FN165] Charles J. Kahane, Ph.D., NAT’L Highway Traffic Safety Admin. ReP. No. DOT HS 808470 (July 1998), Fatality Reduction by Air Bags: Analysis of Accident Data Through Early 1996. available at http://www.nhtsa.dot.gov/cars/rules/regrev/evaluate/808470.html (visited July 27, 2001). 
[FN166] Id.

[FN167] Federal Motor Vehicle Safety Standards; Occupant Crash Protection, 65 Fed. Reg. 30680, 30681 (May 12, 2000) (to be codified at 49 C.F.R. pts. 552, 571, 585, 595).

[FN168] Id.

[FN169] Id.

[FN170] See id. NHTSA estimates that air bags would save 2,400 annually if $85 \%$ of the people used seat belts.

[FN171] Id.

[FN172] H. Moskowitz, supra note 15, at iii. The number of drinks required to produce this BAC depends on gender, weight, and, of course, the alcohol content of the drink. See also Insure.com, How Many Drinks Does It Take? Calculate Your Blood-Alcohol Level at http://www.insure.com/auto/baccalc.html (visited August 10, 2001). This site has a handy calculator for determining BAC using a NHTSA-provided formula, which assumes 0.54 ounces of alcohol in a shot of distilled spirits, a glass of wine, or 12 ounces of beer. Running a few calculations produced the following results. A $170 \mathrm{lb}$ male having 1,2 , or 3 drinks in an hour has a BAC of $0.011,0.033$, or 0.056 . A $140 \mathrm{lb}$ female having 1, 2, or 3 drinks in an hour has a BAC of $0.021,0.053$, or 0.086 .

[FN173] H. Moskowitz, supra note 15, at iii.

[FN174] Id. at 23.

[FN175] 201 F.3d 800 (6th Cir. 2000).

[FN176] Id. at 802.

[FN177] Id. at 804.

[FN178] Id.

[FN179] Id. at 804-805. The court held that the engineer's interpretation of the DERM's data did not constitute indisputable physical facts, but merely an alternative suggestion of events for the jury to resolve.

[FN180] See Lisa Gelhaus, Automaker Must Prove Reliability of Black Box Data, 36 Trial 98 (2000). Remanding the case for a Daubert hearing on this technology "may be the first time an auto-maker has been asked to prove the soundness of its crash-data technology." Id. 
[FN181] Lisa Gelhaus, 'Black Box' Technology Creates Discovery Issues for Lawyers, 36 Trial 56 (2000).

[FN182] Augustus "Chip" Chidester, et al., Recording Automotive Crash Event Data, Int'l Symposium on Transp. Recorders (1999), available at http://www.nhtsa.dot.gov/cars/problems/studies/record/chi-dester.htm (visited July 28, 2001).

[FN183] Id.

[FN184] Id.

[FN185] Gelhaus, supra note 181.

[FN186] Id.

[FN187] Id.

[FN188] Id.

[FN189] Id.

[FN190] Ben Fox, Red Light Cameras Yielding Outcry, The Associated Press Wire, July 19, 2001, available at LEXIS, Academic Universe.

[FN191] Id.

[FN192] Jeanne Wright, Your Wheels; Red-Light Cameras Focus of Disputes, L.A. Times, July 18, 2001, at G1, available at LEXIS, News Library.

[FN193] Fox, supra note 190.

[FN194] AirIQ Inc. available at http://www.airiq.com (visited July 28, 2001).

[FN195] Id.

[FN196] Id.

[FN197] Stephanie Stoughton, Technology \& Innovation; Watching You Watching Them Your Electronic Friends - Car, TV, and Cellphone - May Soon Be The Key To Letting Almost Anyone Peek Into Your Private Life, Boston GLOBE, July 9, 2001, at C4, available at LEXIS, News Library.

[FN198] Id.

[FN199] Id. 
[FN200] Catherine Greenman, The Car Snitched. He Sued., N.Y. Times, June 28, 2001, at G3, available at LEXIS, News Library. A provision in Acme's rental agreement reads: "vehicles driven in excess of posted speed limit will be charged \$150 per occurrence." Id.

[FN201] Id.

[FN202] Id. NHTSA considered, but rejected, a specification for alcohol ignition interlocks that would automatically alert police when the driver failed a rolling retest. Model Specifications for Breath Alcohol Ignition Interlock Devices (BAIIDs), 57 Fed. Reg. 11,772 at 11,781 .

[FN203] Steven Wisotsky, A Society of Suspects: The War on Drugs and Civil Liberties, Cato Research Policy Analysis No. 180, October 2, 1992 at

http:/www.cato.org/pubs/pas/pa-180.html (visited July 28, 2001).

[FN203a] Id.

[FN204] Id.

[FN205] Id.

[FN206] As an example, the courts could authorize interlocks so that the offender can drive to work. An on-board global positioning system would ensure that the driver does not deviate from his assigned route. Cellular phone technology could immediately notify the police if necessary. However, none of these capabilities would be present in the standard interlock.

[FN207] 20775 Pa. Con. Stat. Ann. § 1547(d) (West, WESTLAW through 2000 Reg. Sess.). 